\title{
The Susceptibility of Viruses to Ethyl Ether
}

\author{
By C. H. ANDREWES AND DOROTHY M. HORSTMANN \\ From the National Institute for Medical Research, London, N.W. 3
}

\begin{abstract}
SUMMARY: We have examined by a uniform technique the sensitivity of twentyfive viruses to ethyl ether. Evidence of the sensitivity of ten other viruses is available from the literature. Viruses seem to be either very sensitive or highly resistant. Of the viruses pathogenic to animals, most of the resistant ones are either in the pox group or amongst the very small viruses. The results may prove of use to workers who at times need to separate one virus from mixture with others or with bacteria. The findings may also be of value in any attempt at virus classification.
\end{abstract}

Many records attest that some viruses, notably those of vaccinia and poliomyelitis, are highly resistant to inactivation by ethyl ether. A recent paper by Sulkin \& Zarafonetis (1947) reports that three insect-borne encephalitis viruses (St Louis, Western and Eastern equine encephalomyelitis viruses) are in contrast highly susceptible; that of rabies was found, like poliomyelitis, to be resistant. We were led to test the action of ether on a variety of viruses, to determine how widespread in the group ether-resistance might be.

\section{Methods}

The application of a single simple technique to these viruses was important. We employed pure anaesthetic ethyl ether (May \& Baker, London); this was free from demonstrable peroxides and aldehydes. Tissue suspensions or gradocol membrane filtrates of them were made up in Hartley's broth containing $10 \%$ horse-serum; $20 \%$ ether by volume was added and the mixture placed in a screw-capped bottle. Adhesive tape was bound round the cap to reduce any risk of loss of ether. After being shaken, the bottle was held at $+4^{\circ}$ for $18-24 \mathrm{hr}$. Control specimens were treated similarly but without ether. In many instances, some opalescence or a little readily dispersed precipitate appeared in ethertreated specimens. As a rule little or no layering of ether above the virus suspension was visible after overnight contact. Ether was removed by pouring the specimen into an uncovered Petri dish and allowing evaporation to occur at room temperature; this was rapid, no smell of ether being detected after $10 \mathrm{~min}$. Control and treated specimens were then titrated in the appropriate way in susceptible animals or fertile eggs. Any variation from this technique is recorded in the text.

\section{RESULTS}

The viruses tested were found, in general, to be either wholly resistant to this ether treatment or else highly susceptible. The susceptible viruses mostly had their titre reduced a thousand-fold or more. One or two, however, infected initially only in low dilutions, and an estimate of the amount of inactivation was not possible. The viruses tested will be discussed seriatim. In almost all cases several tests were carried out and the results were concordant. In the 
following account, the viruses we have tested ourselves are numbered; others, the ether sensitivity of which is mentioned in the literature, are referred to but not numbered. The factors by which the titres of the various virus preparations were diminished are recorded in Table 1. In the ether-resistant group there was no demonstrable drop in titre.

\section{Group I. Psittacosis-lymphogranuloma group}

(i) Mouse pneumonitis (Nigg, 1942a). This virus, obtained from our own laboratory mice, was titrated by inoculating centrifuged lung-suspensions intranasally into mice, which were killed 7 days later. Material producing extensive lesions but no deaths at $10^{-5}$ dilution, was, after ether treatment, inactive even when undiluted; $25 \%$ ether was used.

(ii) Feline pneumonitis (Baker, 1944). A virus, provisionally identified thus, was obtained from a cat suffering from chronic catarrh; it was pathogenic for mice and was titrated as for the last virus. Material producing pneumonia at $10^{-4}$ dilution was inactive even undiluted after ether treatment.

Psittacosis (Gordon, 1930-1) and Lymphogranuloma venereum viruses (Nigg, $1942 b$ ) are reported to be susceptible to ether.

\section{Group II. Pox group}

(iii) Vaccinia virus of Salaman's rabbit dermal strain was used in the form of centrifuged suspensions of infected testis and of washed elementary bodies from rabbit skin. Dr A. S. McFarlane kindly provided the latter. The virus was titrated by intradermal inoculation of shaved rabbit skin. Material active at $10^{-6}$ had an identical titre after treatment. Tests on several rabbits gave the same results.

(iv) Infectious ectromelia. Filtrates of infected mouse lung of the Moscow strain of virus were titrated by intraplantar inoculation of mice. These were observed for the development of local lesions and death. Material used infected mice in a $10^{-5}$ dilution, both before and after ether treatment. In one experiment, a little ( $<10$-fold) drop in titre was seen if lesions were used to determine the end-point, but if death was the criterion, the etherized virus was the more active.

(v) Contagious pustular dermatitis. Washed elementary bodies sent us by Mr F. Blakemore were titrated by rubbing falling dilutions into scarified areas of rabbits' skins. Definite lesions developed but their occurrence was rather irregular, so that one had no confidence in reading an end-point. It appeared, however, that the ether treatment affected the titre little or not at all.

Goat-pox and sheep-pox are reported by Bennett, Horgan \& Haseeb (1944) to be resistant to ether.

\section{Group III. Other relatively large viruses (probably heterogeneous)}

(vi) Rabbit myxoma, given us by Dr E. W. Hurst, was used as a centrifuged suspension of infected testis and titrated by intradermal inoculation into rabbits. The titre, in three rabbits, fell respectively from $10^{-4}$ to $10^{-1}, 10^{-5}$ to $10^{-2}, 10^{-5}$ to $10^{0}$. 
(vii) Rabbit fibroma (OA strain), similarly prepared and titrated, fell in titre respectively from $10^{-2}$ to a negative at $10^{0}$ and from $10^{-4}$ to $10^{-1}$. The occurrence of generalized lesions obscured the readings after about the fifth day.

(viii) Grey-lung virus (Andrewes \& Glover, 1945). This virus of mice was titrated in the same way as was Nigg mouse-pneumonitis. Suspensions gave extensive lung lesions at $10^{-4}$ and even this was not an end-point; undiluted ether-treated virus was inactive.

(ix) Herpes simplex. A fairly recently isolated (Syatt) strain was passed through rabbit testes. It gave lesions on intradermal inoculation of rabbits only to a titre of $1: 100$ or $1: 10$. This activity was quite abolished by ether treatment. On passage through mouse-brains it attained an intracerebral titre in mice of $10^{-2}$; again etherized virus was inactive.

(x) B. virus (Sabin, 1934). This virus, which is related to that of herpes, was sent by Dr E. W. Hurst. A centrifuged suspension of infected rabbit brain was titrated intradermally in rabbits. This produced lesions only when undiluted or diluted 1/10. Etherized virus was inactive.

Rabies virus was found by Sulkin \& Zarafonetis (1947) to be ether-resistant; they quote work, however, which suggests that different strains differ in ether resistance.

\section{Group IV. Influenza group}

(xi) Influenza $A$ (PR 8 strain). Infective allantoic fluid was titrated by allantoic inoculation into groups, usually of three eggs; fluids from these were tested for haemagglutinating activity. In three experiments titres dropped as a result of ether treatment, from $10^{-9}$ to $10^{-4}, 10^{-8}$ to $10^{-2}, 10^{-10}$ to $10^{-2}$ respectively. Mouse-lung filtrate titrated similarly in eggs dropped from $10^{-5}$ to $10^{0}$. Material, whether derived from eggs or mice, gave similar results when titrated by intranasal inoculation of mice. The drops in titre obtained were from $10^{-4}$ to $<10^{0}$ (mouse-lung filtrate); and $>10^{-6}$ to $10^{-1}$ and $10^{-5}$ to $10^{-1}$ (allantoic fluid).

(xii) Influenza $B$ (Lee strain). Results with Influenza B were much the same as with A. Ether treatment of allantoic fluid reduced the titre about 100-fold when titrations were made in mice. With allantoic titrations ether treatment caused a drop from $10^{-7}$ to $10^{-1}$.

(xiii) Mumps. Infected allantoic fluid was titrated allantoically, groups of three eggs being used for each dilution. The drop in titre produced by ether treatment was from $10^{-7}$ to $10^{-2}$.

(xiv) Fowl plague. Virus in infected allantoic fluid was titrated in eggs as described for influenza. The drop in titre in a representative experiment was from $10^{-7}$ to $10^{-4}-$ a 1000 -fold.

(xv) Nervcastle-disease virus was similarly examined and the titre fell $10^{5}$-fold, from $10^{-8}$ to $10^{-3}$.

\section{Group V. Tumour viruses}

The Rouse sarcoma and papilloma viruses are considered together here, though it is unlikely that they are related.

(xvi) Rous sarcoma. Filtrates of tumours were titrated by intramuscular 
injection into the breasts and legs of chicks about 6 weeks old; the tumours produced by control filtrates of any one strength were very uniform in size in the six chicks in the experiment. Control material was active at a dilution of 1:1000. After ether treatment tumours of comparable size were produced only by undiluted filtrate.

(xvii) Rabbit papilloma. The warts tested had been kept in glycerol for 12 years and extracts only produced warts on scarification of rabbits' skins when applied undiluted. The ether-treated virus extracts proved, however, equally active with controls. (Drop in titre: nil).

\section{Group VI. Arthropod-transmitted viruses}

(xviii) Yellow fever. A neurotropic virus was received from Dr D. J. Bauer; centrifuged suspensions of infected brains were inoculated intracerebrally in mice and produced deaths up to a dilution of $10^{-3}$. Virus treated with $25 \%$ ether only did so when given undiluted. (Drop in titre $10^{3}$.)

Owing to lack of accommodation in our isolation rooms we carried out only single experiments with the following two viruses.

(xix) Rift-valley fever. Liver suspensions from an infected mouse, again sent by $\mathrm{Dr}$ D. J. Bauer, were titrated intraperitoneally in mice. Control material infected to a titre of $10^{-4}$, ether treated $(20 \%)$ undiluted, doubtfully at $1: 100$.

(xx) Louping-ill. Infective mouse brain, titrated intracerebrally in mice, was active at $10^{-7}$. Etherized virus infected only to a dilution of $10^{-5}$. This virus was provided by $\mathrm{Dr}$ D. G. ff. Edward. The drop in titre of not more than $10^{2}$ is less than that of other viruses in the ether-sensitive groups. It is the smallest virus in this group and may show a transition in properties to group VII.

(xxi) Lymphocytic chorio-meningitis. This virus is potentially arthropodtransmitted, though this is probably not the normal route. Its similarity in size to the others makes it, however, conveniently considered in this group. Since many infected mice do not die, a sharp end-point in titrations of this virus is notoriously difficult to achieve. The WE strain we used was provided by Dr F. O. MacCallum. Brain suspensions were titrated intracerebrally in mice and were active at $10^{-6}$ dilution. Ether-treated suspensions were inactive.

The viruses of St Louis, eastern and western equine encephalomyelitis were reported by Sulkin \& Zarafonetis (1947) to be inactivated by contact with 10 or $20 \%$ ether for $2 \mathrm{hr}$. at $37^{\circ}$. The drop in titre was of the order of $10^{5}$-fold.

\section{Group VII. Very small viruses}

(xxii) Mouse encephalomyelitis (FA strain, Theiler \& Gard 1940). This virus differs in some properties from Theiler's original (TO) mouse encephalomyelitis. Mouse-brain suspensions were, in our hands, infective for mice intracerebrally to a titre of $10^{-5}$ and equally so after ether treatment. We thus confirmed previous reports by Theiler \& Gard (1940) and others. (Drop in titre: nil.)

There are plentiful reports since that of Taylor \& Amoss (1917) of the resistance of human poliomyelitis virus to ether. Sulkin \& Zarafonetis (1947) found that 
the Lansing strain of poliomyelitis virus mixed with ether (to give a final concentration of $95 \%$ ether and $10^{-2}$ virus) and shaken for $2 \mathrm{hr}$. at $37^{\circ}$, showed no loss of infectivity.

Foot-and-mouth disease: Dr I. A. Galloway kindly allows us to quote some experiments carried out at the Virus Research Institute, Pirbright. Ether, $33.3 \%$, was added to potent virus in serum (titre $10^{-4}$ and $10^{-3}$ in two experiments). After short contact at $-22^{\circ}$ the ether was removed and the virus found to be still potent. The ether-treated virus was not titrated.

\section{Group VIII. Bacterial viruses}

(xxiii-xxv) Three phages of different sizes, the relatively large staph $\mathrm{K}$, the intermediate coli-phage C36 and the very small dysentery phage $\mathrm{S} 13$ were treated with ether under the same conditions as with animal viruses. The titres of the three were $4 \times 10^{9} / \mathrm{ml}$., $8 \times 10^{7} / \mathrm{ml}$. and $2 \times 10^{7} / \mathrm{ml}$. before ether treatment, and no appreciable drop in titre was produced by ether in any instance.

Tobacco-mosaic virus. A report by Allard (1916) suggests that tobaccomosaic virus is probably ether resistant.

\section{Conditions affecting the action of ether}

Medium. Several viruses, notably influenza and herpes, were tested as suspensions of tissues derived from different hosts and no evidence was obtained suggesting that such differences affected the results. In some experiments with influenza, it appeared that the titre of material diluted a 100 -fold in saline was diminished more by etherization than that of a similar suspension in serum broth, but the differences were not large. Ectromelia and FA viruses and phage C 36 diluted in saline were still wholly resistant to ether. We carried out no experiment on the effect of ether on purified viruses.

Temperature. McFarlane (1942) has shown that lipid can be extracted from

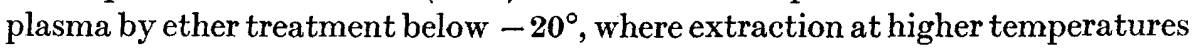
is less complete. We found that the drop in titre caused by ether treatment of influenza $A$, mumps and fowl plague was greater at $-76^{\circ}$ than at $+4^{\circ}$, $10^{6}$-fold as against $10^{4}$-fold in an experiment with influenza $\mathrm{A}$ titrated in eggs, $10^{6}$-fold as against $10^{5}$-fold with mumps, and $10^{6}$-fold against $10^{3}$-fold in a trial with fowl plague. The results were not regular and in one trial with Newcastle disease virus no difference was detected. The resistant viruses vaccinia, ectromelia, FA-encephalomyelitis, rabbit papilloma and phage C36 were still fully resistant when treated at $-76^{\circ}$.

Ether concentration. The tissue extracts studied were approximately saturated by the $20 \%$ of ether added. The few experiments we carried out with weaker $(10 \%)$ or stronger $(25-40 \%)$ ether indicated that many sensitive viruses were definitely affected even by $10 \%$ ether, and that increasing the amount of ether did not succeed in inactivating the resistant ones. Such results accord with those of Sulkin \& Zarafonetis. One would not expect addition of ether above the saturation point to affect the results. 


\section{DISCUSSION}

In Table 1 viruses are arranged vertically, roughly according to size, and to right or left according to their resistance to ether. The ranges of size were allotted in consultation with our colleague Dr W. J. Elford, and are largely based on measurements reviewed by him (Elford, 1938). Study of such an arrangement

Table 1. Viruses arranged according to ether sensitivity and, roughly, size

Group and size range

I. 175-330 $\mathrm{m} \mu$.

IV. 60-120 $\mathrm{m} \mu$.

VI. 20-35 $\mathrm{m} \mu$.
Ether-sensitive

Feline pneumonitis $\left[>10^{4}\right]$

Mouse pneumonitis $\left[>10^{5}\right]$

(Psittacosis)

(Lymphogranuloma

venereum)

III. $150-200 \mathrm{~m} \mu$.

Grey lung virus $\left[>10^{4}\right]$

Rabbit myxoma $\left[10^{3}-10^{5}\right]$

Rabbit fibroma [10 $\left.{ }^{2}\right]$

Herpes simplex $\left[>10^{2}\right]$

B. Virus $[>10]$

Influenza $A\left[10^{4}-10^{8}\right]$

Influenza $B\left[10^{2}-10^{6}\right]$

Mumps [10 $]$

Fowl plague $\left[10^{3}\right]$

Newcastle disease $\left[10^{5}\right]$

Rous sarcoma [10 $]$

Lymphocytic choriomeningitis $\left[>10^{6}\right]$

Rift valley fever [10²]

(St Louis encephalitis $\left[10^{5}\right]$ )

(Western equine encephalomyelitis $\left.\left[10^{5}\right]\right)$

(Eastern equine encephalomyelitis $\left[10^{5}\right]$ )

Yellow fever $\left[10^{3}\right]$

Louping-ill $\left[10^{2}\right]$
Group and size range

II. 150-200 $\mathrm{m} \mu$.

Vaccinia

Infectious ectromelia

? Contagious pustular dermatitis

(Goat-pox)

(Sheep-pox)

(Rabies)

\author{
30-50 m $\mu$. Rabbit papilloma \\ VIII. 50-75 $\mathrm{m} \mu$. Bacteriophage Staph. K \\ 20-30 m $\mu$. Bacteriophage C36 \\ 8-12 $\mathrm{m} \mu$. Bacteriophage S13
}

VII. 8-15 $\mathrm{m} \mu$.

(Foot-and-mouth disease) (Human poliomyelitis)

Mouse encephalomyelitis (FA)

Viruses in round brackets have been examined by other workers, usually by techniques rather different from our own. The factor by which the titre of each ether-sensitive virus preparation was diminished is cited in square brackets.

may be helpful in enabling one to approach a little nearer to a classification of viruses. Many viruses which we had no opportunity to study will not fall conveniently into any of the rough groupings we have used in this paper and in the table. There is an interesting and perhaps significant correlation between our results and those of Wilson Smith (1939) on the bile-salt sensitivity of viruses. He found by experiment or from records in the literature that the following (all ether-sensitive) were inactivated by bile salts: influenza $\mathbf{A}$, louping-ill, Rous sarcoma; whereas poliomyelitis, foot-and-mouth disease, vaccinia and ectromelia, all ether-resistant, also resisted bile salts. Rabies however, is said to be ether-resistant, yet sensitive to bile salts. It was 
certainly resistant in Sulkin \& Zarafonetis's tests, but according to Remlinger (1919) is slowly inactivated when infected brain is immersed in pure ether. Psittacosis, on the other hand, according to Burnet \& Lush (1940), is resistant to bile-salts, though we find it ether-sensitive. On the whole the viruses which we have found to be ether-resistant are 'tough' viruses, viruses which can be left at room temperature without fear that they will quickly lose activity. The ether-sensitive ones are, on the whole, more delicate.

$\mathbf{A}$ few discrepanciès in our results must be mentioned. Influenza $\mathbf{A}$ and $B$ virus were invariably reduced $10^{4}$-fold or more in titre by ether when titrated allantoically: when, however, mouse inoculation was used, a few of our earlier experiments, especially with Influenza B virus of low titre, showed little or no inactivation. Again, vaccinia was apparently wholly resistant whenever titrated intradermally in rabbits, but, according to our colleague Dr K. R. Dumbell, showed a drop in titre after ether treatment when titrated by counting pocks on the chorioallantoic membrane. Using this same technique Dr F. O. MacCallum found a similar effect of ether on variola. As yet, our efforts to account for these discrepancies have been unsuccessful. Other workers seem agreed that influenza viruses are ordinarily ether-sensitive, while vaccinia is not.

One cannot readily correlate our findings with what is known of the chemical composition of viruses. Viruses known to contain both protein and lipids occur in both sensitive and resistant categories. Possibly the arrangement of the virus-components is important-whether or not, for instance, lipid occurs on the surface of the particles. One cannot easily exclude the possibility that in apparent inactivation by ether, aggregation at times plays a part. Such aggregation has, however, been equally apparent in preparations of sensitive and resistant viruses. Aggregates formed have been largely broken up by gentle shaking. Moreover, the complete inactivation or 1000-fold drop in titre shown by most of the sensitive viruses can certainly not be explained in such a way.

We wish to thank the workers named in the text and others who have kindly supplied us with material for test. One of us (D.M.H.) was in receipt of a travelling fellowship from the National Institute of Health, Washington.

\section{REFERENCES}

Allard, H. A. (1916). Some properties of the virus of the mosaic disease of tobacco. J. agric. Res. 6, 649.

Andrewes, C. H. \& Glover, R. E. (1945). Grey lung virus: an agent pathogenic for mice and other rodents. Brit. J. exp. Path. 26, 379.

BAKER, J. A. (1944). A virus causing pneumonia in cats and producing elementary bodies. J. exp. Med. 79, 159.

Bennett, S. C. J., Horgan, E. S. \& Haskeb, M. A. (1944). The pox diseases of sheep and goats. J. comp. Path. 54, 131.

Burnet, F. M. \& Lush, D. (1940). The action of certain surface-active agents on viruses. Aust. J. exp. Biol. med. Sci. 18, 141.

Elforo, W. J. (1938). The sizes of viruses and bacteriophages and methods for their determination. Handbuch der Virus forschung, Vienna. Doerr, R. \& Hallauer, C. (editors), 1 Hälfte, p. 126. Wien: Springer. 
Gordon, M. H. (1930-1). A disease of parrots communicable to man (psittacosis). Rep. publ. Hlth med. Subj., Lond., no. 61, p. 101.

McFarlane, A. S. (1942). Behaviour of lipoids in human serum. Nature, Lond., $149,439$.

NigG, C. (1942a). An unidentified virus which produces pneumonia and systemic infection in mice. Science, $95,49$.

NigG, C. (1942b). Action of urea and ether on agent and complement-fixing antigen of lymphogranuloma inguinale. Proc. Soc. exp. Biol., N.Y., 49, 132.

Remlinger, P. (1919). Action de l'ether sur le virus rabique. Ann. Inst. Pasteur, 33, 616.

SABIN, A. B. (1934). Acute ascending myelitis following a monkey bite, with the isolation of a virus capable of reproducing the disease. J. exp. Med. 59, 115.

Smrth, W. (1939). The action of bile salts on viruses. J. Path. Bact. 48, 557.

Sulkin, S. E. \& Zarafonetis, C. (1947). Influence of anaesthesia on experimental neurotropic virus infections. II. In vitro studies with viruses of western and eastern equine encephalomyelitis, St Louis encephalitis, poliomyelitis (Lansing) and rabies. J. exp. Med. 85, 559 .

TAYLOR, E. \& Amoss, H. L. (1917). Carriage of the virus of poliomyelitis with subsequent development of the infection. J. exp. Med. 26, 745 .

Theiler, M. \& Gard, S. (1940). Encephalomyelitis of mice. I. Characteristics and pathogenesis of the virus. J. exp. Med. 72, 49.

(Received 8 November 1948) 